\title{
Pyogenic Granuloma: Retrospective Analysis of Eleven Cases with Literature Data
}

\author{
Piyojenik Granülom: On-bir Olgunun Literatür Verileri Eşliğinde Retrospektif Analizi
}

\author{
(D) Bahtiyar Hamit1, (D) Suat Bilici1, (D) Özgür Yiğit1, (D) Erol Rüștü Bozkurt² \\ 1istanbul Training and Research Hospital, Clinic of Otorhinolaryngology, i̇stanbul, Turkey \\ 2istanbul Training and Research Hospital, Clinic of Pathology, İstanbul, Turkey
}

\begin{abstract}
Introduction: The aim of the present study was to determine the demographic characteristics of patients undergoing surgery for pyogenic granuloma (PG) in our clinic and to discuss them with the literature data.

Methods: The patients who were reported as PG after pathology results were analyzed in terms of age, gender, tumor localization, tumor size, etiologic factors, time of occurrence and recurrence.

Results: The ages of 11 patients diagnosed with PG ranged from 14 to 62 years with a mean age of 42.36 years. Eight patients were between 30-60 years old. Five patients were female (45.45\%) and six were male (54.55\%). Oral cavity localization (tongue in three patients, hard palate in one patient, and both tongue and buccal mucosa in one patient) was observed in five patients. Nose localization (septum in two patients, inferior concha in one patient, and middle concha in one patient) was observed in four patients and two patients had skin localization (scalp in one patient and back of auricle in one patient). Onset of symptoms varied between 2 and 21 weeks (mean: 10.36 weeks). Tumor size varied between 5 and $25 \mathrm{~mm}$ (mean: 11.33 $\mathrm{mm}$ ). There were seven pedunculated lesions and four nodular lesions among all specimens.
\end{abstract}

Conclusion: $\mathrm{PG}$ is a diagnosis that should be kept in mind in the differential diagnosis of rapidly growing, hemorrhagic oral cavity and unilateral nasal masses. Total excision of the lesion with intact mucosal margins is required to prevent recurrence.

Keywords: Pyogenic granuloma, lobular capillary hemangioma, oral cavity, nasal obstruction, epistaxis

\section{öz}

Amaç: Bu çalışmanın amacı kliniğimizde piyojenik granülom nedeniyle opere edilen hastaların demografik özelliklerini belirlemek ve literatür verileri eșliğinde tartıșmaktır.

Yöntemler: Patoloji sonucu piyojenik granülom olarak rapor edilen hastalar yaş, cinsiyet, tümör lokalizasyonu, tümör boyutu, etiyolojik faktörler, ortaya çıkma zamanı ve nüks açısından incelendi.

Bulgular: Piyojenik granülom tanısı alan 11 hastanın yaşları 14 ile 62 arasında değișmekteydi ve ortalama yaş 42,36 idi. Sekiz hastanın yașı 30-60 arasındaydı. Hastaların 5’i kadın $(\% 45,45)$ ve 6 'sı erkekti $(\% 54,55)$. Beș hastada $(\% 45,45)$ oral kavite (3 dil, 1 sert damak ve 1 hastada hem dil hem de yanak mukozası), 4 hastada $(\% 36,36)$ burun (2 septum, 1 alt konka ve 1 orta konka) ve 2 hastada $(\% 18,18)$ deri (1 skalp ve 1 aurikula arkası) yerleșimi gözlendi. Semptomların görülme zamanı 2-21 hafta (ortalama: 10,36) arasında değișmekteydi. Tümör boyutu 5-25 mm (ortalama: 11,33 mm) arasında değișmekteydi. Tüm piyesler içerisinde 7 pedinküllü ve 4 nodüler lezyon mevcuttu.

Sonuç: Piyojenik granülom özellikle kanamalı hızlı büyüyen oral kavite lezyonlarının ve tek taraflı burun kitlelerinin ayırıcı tanısında akılda tutulması gereken bir tanıdır. Rekürrensi önlemek amacıyla lezyonun sağlam mukozal sınırlar ile total eksizyonu gerekmektedir.

Anahtar Kelimeler: Piyojenik granülom, lobüler kapiller hemanjiom, oral kavite, burun tıkanıklığı, burun kanaması

\section{Introduction}

Pyogenic granuloma (PG) is a benign vascular lesion with no known cause. It is usually observed on skin and mucous membranes. It generally presents as a red, frequently bleeding, pedunculated or nodular painless lesion and rarely mimics a malign mass due to rapid growth $(1,2)$.
Trauma, chronic irritation and hormonal changes are accused in the etiology (3). PG can also be observed in other parts of the body, most frequently in head and neck region. It can be seen frequently in the oral cavity and more rarely in the nasal cavity and larynx in head and neck region $(1,4,5)$. 
The aim of the present study was to determine the demographic characteristics of the patients undergoing surgery for PG in our clinic and to discuss them with literature data.

\section{Methods}

This retrospectively designed study was approved by İstanbul Training and Research Hospital Local Ethics Committee (decision no: 1040, date: 21.07.2017). The files of patients who underwent surgery under local and general anesthesia between 2013 and 2016 in clinic of otorhinolaryngology were retrospectively reviewed and patients who were reported as PG after pathology result were included in the study. Informed consent was obtained from all patients included in the study. The patients were examined in terms of age, gender, tumor localization, tumor size, etiologic factors, time of occurrence and recurrence.

\section{Statistical Analysis}

Statistical analysis program was not used to evaluate the study data. Continuous variable were expressed as mean and categorical variables as percentage.

\section{Results}

A total of 11 patients who were operated at the otorhinolaryngology clinic were diagnosed with PG. The age of the patients ranged from 14 to

Table 1. Distribution of age and localization in terms of gender

\begin{tabular}{|c|c|c|c|c|}
\hline & & Male & Female & Total \\
\hline \multirow{3}{*}{ 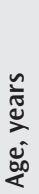 } & $<20$ & 2 & 0 & 2 \\
\hline & $30-50$ & 1 & 4 & 5 \\
\hline & $50<$ & 3 & 1 & 4 \\
\hline \multirow{3}{*}{ 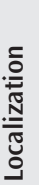 } & Oral cavity & 4 & 1 & 5 \\
\hline & Nose & 1 & 3 & 4 \\
\hline & Skin & 1 & 1 & 2 \\
\hline
\end{tabular}

62 years with a mean age of 42.36 years. All demographic characteristics of patients are shown in Table 1, 2.

No etiology was determined in nine patients (81\%). PG was determined to develop on hard palate in one patient after hot meal and in tongue and buccal mucosa at the same side in the other patient due to irritation associated with decay tooth. There was no history of nasal trauma, surgical intervention or tampon application in any patients. All female patients had at least one history of delivery and had no history of oral contraceptive use and gynecologic malignity. There were no pregnant patients.

Paranasal sinus computed tomography (CT) and magnetic resonance imaging (MRI) were performed in two patients with unilateral nasal obstruction and epistaxis. PG was reported to be hypointense on T1-weighted images (WI), and hyperintense on T2-WI with contrast enhancement (Figure 1) in MRI, and polyploidy soft tissue mass with smooth surface, without bone destruction in CT (Figure 2). In all

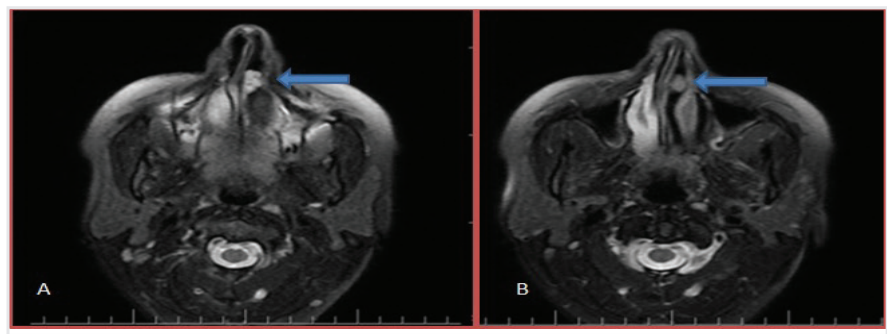

Figure 1. Axial T1 (A) and T2 (B) magnetic resonance images

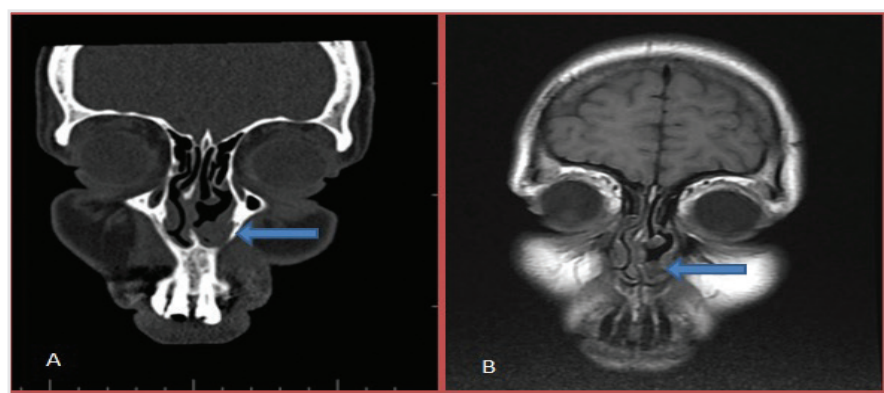

Figure 2. Coronal computed tomography (A) and T1-weighted magnetic resonance $(\mathrm{B})$ images

Table 2. Table of all data

\begin{tabular}{|c|c|c|c|c|c|c|c|c|}
\hline Case & Age & Gender & Size $(\mathrm{mm})$ & Time (Week) & Peduncle & Symptom & Etiology & Localization \\
\hline 1 & 36 & $\mathrm{~F}$ & 10 & 16 & Yes & Mass & Unknown & Scalp \\
\hline 2 & 45 & $\mathrm{~F}$ & 15 & 5 & No & Hemorrhage obstruction & Unknown & Left inferior turbinate \\
\hline 3 & 52 & $\mathrm{~F}$ & $6+8$ & 8 & Yes & Mass & Dental irritation & Tongue + right buccal mucosa \\
\hline 4 & 36 & $\mathrm{~F}$ & 25 & 21 & Yes & Hemorrhage obstruction & Unknown & Right middle turbinate \\
\hline 5 & 49 & $\mathrm{~F}$ & 17 & 5 & No & Hemorrhage & Unknown & Left septum \\
\hline 6 & 42 & M & 15 & 2 & No & Hemorrhage obstruction & Unknown & Left septum \\
\hline 7 & 19 & $M$ & 7 & 15 & No & Mass & Unknown & Tongue \\
\hline 8 & 14 & M & 8 & 8 & Yes & Mass & Unknown & Tongue \\
\hline 9 & 62 & M & 12 & 9 & Yes & Mass hemorrhage & Unknown & Tongue \\
\hline 10 & 59 & M & 5 & 17 & Yes & Mass & Unknown & Back of right auricle \\
\hline 11 & 52 & M & 8 & 8 & Yes & Mass hemorrhage & Hot & Hard palate \\
\hline
\end{tabular}




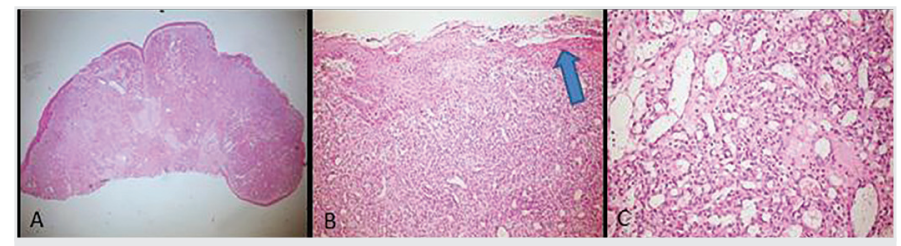

Figure 3. Postoperative histopathological examination (B: arrow shows ulceration of squamous epithelium)

patients, PG was excised totally as a solid mucosal margin around the mass. Postoperative recurrence was not observed after a mean followup period of 27 months (range: 12-48 months).

Histopathological examination (Figure 3) revealed a lobular polyploidy lesion at small magnification (A). At greater magnification (B), granulation tissue consisting of numerous vascular structures, hyalinized connective tissue and inflammatory cells was observed under squamous epithelium showing ulceration (arrow in right upper corner) and reactive changes. At a greater magnification (C), sporadically swollen endothelial cells with open lumens and thin wall in various sizes and forms, with some having a dilated appearance as well as numerous vascular structures and infiltration of mixed inflammatory cells in partially edematous hyalinized stroma were observed.

\section{Discussion}

PG is a rapidly growing, vascular and benign inflammatory lesion involving the skin and mucous membranes $(1,2)$. The lesion was defined by Hullihen in 1844 for the first time and named as Granuloma Pyogenicum by Hertzell in 1904 (3). It was suggested that this denomination was wrong upon the fact that no bacterial infectious agent was determined in series of subsequently reported cases and granuloma was not identified in histopathological examinations. It is recommended to use the term lobular capillary hemangioma by Mills et al. (6), in 1980. Nevertheless, the term "PG" is used very commonly in the literature.

Even though the cause of PG is unknown, increased hormonal activity is the most implicated factor because it is frequently seen in pregnant women, and this lesion was also named as pregnancy tumor by some authors (7). The use of oral contraceptive and some gynecologic malignancies have been suggested to likely play a role in the etiology by changing the hormonal balance in the body, as well. Chronic irritation, nasal trauma and surgical procedures, disordered oral hygiene, habit of biting lips, and intranasal tampon application are also factors to be accused in etiology (8-12). Although there are cases of PG developing after blunt laryngeal trauma and insect sting in the literature, no distinct etiological cause has been determined in several studies $(13,14)$. In the present study, etiological cause could not be determined in nine patients (81\%) except for one female patient with lesion on buccal mucosa and lateral side of tongue as a result of chronic irritation associated with tooth decay and one male patient with lesion developing on hard palate after hot meal.

Even though PG is observed in neonatal age and childhood, it is identified mostly in the third decade and more frequently in women $(15,16)$. While it is more frequent in men, particularly in childhood, the incidence is higher in women during adulthood (17). In the present study, while there were two male patients under the age of 20 years, the female-male ratio for age interval of 30-50 years was found to be $4 / 1$. This ratio suggests that levels of estrogen and progesterone in the body may play a role in the etiology.

PG most frequently involves the skin and mucous membranes in the body. In a case series of 82 patients published by Akamatsu et al. (4), PG was most frequently localized in the head-neck region at a rate of $56 \%$, in the upper extremities at a rate of $22 \%$, in the torso at a rate of $16 \%$, and in the lower extremities at a rate of $6 \%$. It was observed that the most common localization was oral cavity and nasal mucosa in cases with PG localized in the head and neck region (4).

PG is diagnosed by excisional biopsy. In histopathological examination, it appears as an atrophic granulation tissue covered with fibrous tissue or increased granulation tissue covered with hyperplastic epithelial tissue. The presence of fibroblasts increased with vascular gaps covered by numerous endothelial and clustered endothelial cells constituted characteristic microscopic appearance of PG. It is described in three stages depending on the prognosis of the lesion. At the cellular stage, small lumen formations are observed within the compact cellular stroma. While increased vascular lobules filled with erythrocytes are observed at capillary stage, fibrosis is observed to develop in and around lobules at late stage (18).

PG was found at a rate of $3.2 \%$ among all of the biopsies taken from oral cavity (11). In other series, PG was identified at the rates of $21 \%$ and $50.35 \%$ in all oral cavity biopsies taken from tumor-like soft tissues $(10,12)$. While gingiva is mostly involved at a rate of $83-93.95 \%$ in oral cavity, tongue, lip, palate, and buccal mucosa are involved less (10-12). The reason behind why gingival involvement was not observed in the present study was thought to be associated with the fact that these patients applied to dentistry instead of otorhinolaryngology. Six lesions were found in the oral cavity of five patients including four tongue localizations, one hard palate localization, and one buccal mucosa localization.

In a case series with 38 patients with nasal cavity localization, PG was most frequently associated with septum at a rate of $71 \%$, nasal base at $13 \%$, inferior turbinate at 13\%, and middle turbinate at $3 \%$ (8). Right and left localization was found to be at a similar rate (8). In the present study, two lesions were associated with septum and one lesion was associated with inferior turbinate had left (75\%) localization; whereas, one lesion was associated with middle turbinate had right (25\%) localization. However, this rate was considered to be insignificant due to low number of patients.

PG may have various symptoms depending on localization and size. While the most frequent symptom is mass and hemorrhage for lesions localized in oral cavity, episodic epistaxis (95\%) and nasal obstruction $(35 \%)$ at affected side are the most frequent symptoms for nasal lesions $(11,19)$. Rhinorrhea, facial pain, hyposmia and headache are less common symptoms (19).

In patients with PG localized in the oral cavity, differential diagnosis should be established with fibrous hyperplasia, peripheral giant cell 
granuloma, fibroma and hemangioma (12). In nasal lesions, differential diagnosis of masses such as inverted papilloma, capillary hemangioma, meningoencephalocele, adenocarcinoma, hemangiopericytoma, esthesioneuroblastoma, angiosarcoma, Kaposi sarcoma, and lymphoma should be made $(8,9,19)$. Differential diagnosis should be made with Kaposi's sarcoma in localized lesions of the skin (20). Radiological imaging may be needed to support the diagnosis and establish differential diagnosis for suspicious lesions (9). Polypoid soft tissue mass with smooth surface and no bone destruction in $\mathrm{CT}$ and hypointensity on T1-WI, hyperintensity on T2-WI and proper contrast enhancement in MRI was determined in two cases with intranasal localization.

Although PG often appears to be a single lesion, the so called scattered PG in which more than 100 lesions occur on the same patient has also been reported in the literature (21). It was observed as a single lesion in all patients except for one woman with two simultaneous lesions on the lateral side of tongue and buccal mucosa at the same side based on tooth irritation.

Recurrence of lesion is rare after total excision. While oral cavity lesions are mostly excised under local anesthesia, excision under general anesthesia accompanied with endoscope is recommended for large nasal lesions (22). In the present study, skin and oral cavity lesions were excised under local anesthesia. Nasal lesions were excised with endoscope; septal lesions were excised under local anesthesia, and lesions associated with inferior and middle turbinate were excised under general anesthesia. Recurrence was observed in $0-8 \%$ in the nasal cavity and $2-14.88 \%$ in the oral cavity at $1-5$ years of follow-up $(8-10,12)$. Insufficient excision, failure of eliminating etiological factors and repetitive traumas have been shown as the cause of recurrence and re-recurrence after revision surgery has also been reported (12). Postoperative recurrence was not observed in the present study after a mean follow-up of 27 months (range: 12-48 months).

\section{Conclusion}

PG is a rare diagnosis in otorhinolaryngology practice and it should be considered especially in the differential diagnosis of rapidly developing oral cavity and unilateral nasal masses. In order to prevent recurrence, total excision of the lesion with solid mucosal margins is required.

Ethics Committee Approval: This retrospectively designed study was approved by İstanbul Training and Research Hospital Local Ethics Committee (decision no: 1040, date: 21.07.2017).

Informed Consent: Informed consent was obtained from all patients included in the study.

Peer-review: Externally peer-reviewed.

Author Contributions: Concept - B.H., S.B., Ö.Y., E.R.B.; Design - B.H., S.B., Ö.Y., E.R.B.; Data Collection and/or Processing - B.H., S.B., E.R.B.; Analysis and/or Interpretation - B.H., S.B., E.R.B.; Literature Search - B.H., S.B.; Writing Manuscript - B.H., S.B.

Conflict of Interest: No conflict of interest was declared by the authors.

Financial Disclosure: The authors declared that this study received no financial support.

\section{References}

1. Karlıdağ T, Yalçın \$̦, Akpolat N. Pyogenic granuloma of the epiglottis: A case report. Türk Otolarengoloji Arșivi 2007; 45: 41-4.

2. Kurtaran H, Uraldi C, Ark N, Aktaş D. Lobular capillary haemangioma of the middle turbinate. Acta Otolaryngol 2006; 126: 442-4.

3. Punde PA, Malik SA, Malik NA, Parkar M. Idiopathic huge pyogenic granuloma in young and old: An unusually large lesion in two cases. J Oral Maxillofac Pathol 2013; 17: 463-6.

4. Akamatsu T, Hanai U, Kobayashi M, Miyasaka M. Pyogenic granuloma: A retrospective 10-year analysis of 82 cases. Tokai J Exp Clin Med 2015; 40: 1104.

5. Akman K, Aydin E, Ozen O, Ozluglu L. Lobular capillary hemangioma of the middle turbinate. Turk Arch Otolaryngol 2007; 45: 48-51.

6. Mills SE, Cooper PH, Fechner RE. Lobular capillary hemangioma: the underlying lesion of pyogenic granuloma. A study of 73 cases from the oral and nasal mucous membranes. Am J Surg Pathol 1980; 4: 47047-9.

7. Delbrouck C, Chamiec M, Hassid S, Ghanooni R. Lobular capillary haemangioma of the nasal cavity during pregnancy. J Laryngol Otol 2011; 125: $973-7$.

8. Lopez A, Tang S, Kacker A, Scognamiglio T. Demographics and etiologic factors of nasal pyogenic granuloma. Int Forum Allergy Rhinol 2016; 6: 1094-7.

9. el-Sayed Y, al-Serhani A. Lobular capillary haemangioma (pyogenic granuloma) of the nose. J Laryngol Otol 1997; 111: 941-5.

10. Saravana GH. Oral pyogenic granuloma: a review of 137 cases. Br J Oral Maxillofac Surg 2009; 47: 318-9.

11. Gordón-Núñez MA, de Vasconcelos Carvalho M, Benevenuto TG, Lopes MF, Silva LM, Galvão HC. Oral pyogenic granuloma: a retrospective analysis of 293 cases in a Brazilian population. J Oral Maxillofac Surg 2010; 68: 2185-8.

12. Krishnapillai R, Punnoose K, Angadi PV, Koneru A. Oral pyogenic granuloma-a review of 215 cases in a South Indian Teaching Hospital, Karnataka, over a period of 20 years. Oral Maxillofac Surg 2012; 16: 305-9.

13. Derkenne R, Coulet O, Varoquaux A, de Biasi C, Tomasi M. Nasal cavity lobular capillary hemangioma due to insect sting. Eur Ann Otorhinolaryngol Head Neck Dis 2012; 129: 278-80.

14. Garrett MM, Lee WT. Obstructing pyogenic granuloma as a result of blunt laryngeal trauma. Otolaryngol Head Neck Surg 2007; 136: 489-90.

15. Walner DL, Parker NP, Kim OS, Angeles RM, Stich DD. Lobular capillary hemangioma of the neonatal larynx. Arch Otolaryngol Head Neck Surg 2008; 134: $272-7$.

16. Simo R, de Carpentier J, Rejali D, Gunawardena WJ. Paediatric pyogenic granuloma presenting as a unilateral nasal polyp. Rhinology 1998; 36: 136-8.

17. Ozcan C, Apa DD, Görür K. Pediatric lobular capillary hemangioma of the nasal cavity. Eur Arch Otorhinolaryngol 2004; 261: 449-51.

18. Marla V, Shrestha A, Goel K, Shrestha S. The histopathological spectrum of pyogenic granuloma: A case series. Case Reports in Dentistry 2016; 2016:1323798.

19. Puxeddu R, Berlucchi M, Ledda GP, Parodo G, Farina D, Nicolai P. Lobular capillary hemangioma of the nasal cavity: A retrospective study on 40 patients. Am J Rhinol 2006; 20: 480-4.

20. Megaly M, Boshra N. Pyogenic granuloma-like Kaposi's sarcoma. Lancet 2015; 20. pii: S0140-6736.

21. Nappi O, Wick MR. Disseminated lobular capillary hemangioma (pyogenic granuloma). A clinicopathologic study of two cases. Am J Dermatopathol 1986; 8: 379-85

22. Bhattacharyya N, Wenokur RK, Goodman ML. Endoscopic excision of a giant pyogenic granuloma of the nasal cavity caused by nasal packing. Rhinology 1997; 35: 44-5. 